\title{
KARAKTERISTIK FASAD RUMAH MINIMALIS DI SURAKARTA
}

\author{
Mufti Arifin, Samsudin \\ Program Studi Teknik Arsitektur, Fakultas Teknik, Universitas Muhammadiyah Surakarta \\ Jl. A. Yani Tromol Pos 1 Pabelan Kartasura Sukoharjo 57102 Telp 0271-717417 \\ E-mail: raidi_samsudin@yahoo.co.id
}

\begin{abstract}
ABSTRAK
Berbagai jenis desain rumah berkembang di Surakarta, antara lain desain rumah minimalis, modern, mediterania, klasik dan sebagainya. Salah satu yang berkembang adalah model disain minimalis. Berbagai bentuk model minimalis dapat ditemui di masyarakat. Penelitian ini dilakukan untuk mencari jawaban tentang karakteristik dan ciri fasad disain rumah minimalis. Pengambilan data dilakukan dengan menggunakan alat bantu kamera dan meliputi seluruh wilayah Surakarta. Kompenen-kompenen fasad bangunan rumah minimalis yang dianalisis meliputi bentuk, orientasi, warna, dimensi, proporsi, irama dan skala. Simpulan dari kegiatan ini adalah bentuk/wujud bangunanya merupakan bangunan yang sedarhana, geometris dan simple, posisi bangunan sangat strategis yang dapat dilihat dari barbagai arah, warna didominasi warna putih abu-abu, dimensi cukup kecil dari bangunan sekitarnya, irama kebanyakan diperlihatkan pada ventilasi dan jendela dan penggunaan material batu alam dan skala keseluruhan bangunan relatif besar dan didukung dari kondisi bangunan yang masih terlihat bagus.
\end{abstract}

Kata Kunci: rumah, fasad, minimalis

\section{PENDAHULUAN}

Surakarta merupakan kota yang berkembang dengan jumlah penduduk yang padat, sehingga banyak terjadi pembangunan rumah. Disain rumah yang ada mengikuti perkembangan zaman salah satunya yang berkembang adalah desain rumah minimalis. Rumah minimalis hadir dengan karakter lebih jelas (bentuk dan ruang geometris dan sederhana), lebih baik (kukuh), dan lebih kuat dengan ruang-ruang yang kosong (sedikit ornamen dan perabotan). Namun terlalu minimalis akan cenderung membosankan. Untuk itu, perlu dipahami bersama cara pengembangan dasar rumah minimalis dalam konteks budaya masayarakat urban kita.

Dengan melihat bangunan model minimalis yang berada di Surakarta dari fasad bangunannya, maka permasalahan yang akan dicari jawabannya adalah bagaimana karakteristik fasad rumah minimalis ditinjau dari unsur - unsur bentuk dan bagaimana ciriciri fasad rumah minimalis

Tujuan penelitian ini untuk mengetahui karakteristik fasade rumah minimalis yang berada di Kota Surakarta.

\section{TINJAUAN PUSTAKA Fasad}

Definisi fasad menurut Krier (2001), kata fasade diambil dari kata latin "facies" yang merupakan sinonim kata-kata face (wajah) dan appearance (penampilan). Karena itu, fasad diterjemahkan sebagai bagian depan yang menghadap jalan.

Krier (2001) menjelaskan komposisi fasad harus mempertimbangkan persyaratan fungsional yaitu jendela, bukaan pintu, pelindung matahari dan bidang atap. Desain fasad pada dasarnya berkaitan dengan penciptaan kesatuan harmonis antara proporsi yang baik, penyusunan struktur vertikal dan horisontal, ritme bahan, warna dan elemen dekoratif. Sebagai suatu kese-luruhan, fasad tersusun dari beberapa elemen tunggal yaitu entrance dan pintu masuk, arcade, lantai dasar, jendela, balkon, dan logia, serta atap. Komposisi fasad terdiri dari penstrukturan disatu sisi dan penataan pada sisi lainnya. Elemen-elemen fasad itu merupakan benda yang berbeda sehingga memiliki bentuk, warna dan bahan yang berbeda pula. 
Komposisi Visual

Komposisi visual meliputi :

\section{a. Geometri}

Gantini (1996) menyatakan bahwa geometri memiliki unsur-unsur yaitu garis/ batang/ sisi/ rusuk, sudut dan bidang/ lempeng. Menurut Krier (2001), geometri ter-bagi menjadi dua yaitu beraturan dan tidak beraturan. Geometri dasar bangunan terdiri atas tiga jenis yaitu bujursangkar, segitiga, dan lingkaran.

b. Tekstur

Tekstur adalah nilai raba pada suatu permukaan, baik itu nyata maupun semu. Suatu permukaan mungkin kasar, halus, keras atau lunak, kasar atau licin. (Sidik dan Prayitno, 1979: 26 dalam I Wayan Gulendra). Tekstur merupakan karakter nilai raba yang dapat dirasakan secara fisik dan secara imajiner.

\section{c. Bidang Solid Void}

Bidang void pada fasad berupa bukaan pintu dan jendela yang berfungsi untuk memasukan udara dan cahaya ke dalam ruangan. Bukaan jendela yang terus menerus berulang, yang bersama elemen dinding, menciptakan kontras permukaan terbuka-tertutup, gelap-terang, kasar dan halus

\section{Unsur-Unsur bentuk Bangunan}

Pada proses analisa tentang fasad bangunan dari masing-masing bangunan obyek penelitiaan ini, digunakan aspek-aspek variabel penelitian berupa ciri-ciri visual bentuk atau unsur-unsur bentuk bangunan (DK.Ching,1979). Adapun penjelasan untuk masing-masing unsur-unsur bentuk bangunan tersebut antara lain :

a. Wujud, merupakan ciri-ciri pokok yang menunjukkan bentuk. Wujud adalah hasil konfigurasi tertentu dari permukaanpermukaan dan sisi-sisi suatu bentuk.

b. Dimensi dan proporsi, dimensi suatu bentuk adalah panjang, lebar dan tinggi. Dimensi-dimensi ini menentukan proporsi dari suatu bangunan.

c. Warna, adalah corak, intensitas dan nada pada permukaan suatu bentuk. Warna adalah atribut yang paling mencolok yang membedakan suatu bentuk terhadap lingkunganya. Warna juga mempengaruhi bobot visual suatu bentuk. d. Tekstur, adalah karakter permukaan suatu bentuk. Tekstur mempengaruhi baik perasaan seseorang pada waktu menyentuh maupun kwalitas pemantulan cahaya menimpa permukaan bentuk tersebut.

e. Posisi, adalah letak relatif suatu bentuk terhadap suatu lingkungan atau medan visual.

f. Orientasi, adalah posisi relatif suatu bentuk terhadap bidang dasar, arah mata angin, atau terhadap pandangan seseorang yang melihatnya.

g. Skala, adapun skalanya ditentukan oleh perbandingan ukuran relatifnya terhadap bentuk-bentuk lain disekelilingnya.

h. Irama, adalah suatu pola tertentu yang tampak pada bidang fasad bangunan, yang dapat memperkuat karakter bangunan tersebut.

\section{Elemen Penyusun Fasad.}

Menurut Rayhan (2009) fasad terbentuk dari elemen-elemen arsitektur, antara lain atap pintu, jendela, material bangunan, finishing, dan warna. Oleh karena itu, fasad berpengaruh terhadap produk akhir arsitektur.

\section{Arsitektur Gaya Minimalis}

Minimalis adalah pola berpikir, bekerja, dan suatu cara hidup. Sebuah cara pandang baru dalam melihat desain sebagai refleksi cara hidup masyarakat urban yang serba praktis, ringan, efisien, dan penuh kesederhaan.

Paham minimalis muncul sebagai protes terhadap keadaan masyarakat yang tidak menghargai sumber daya alam dengan mengeksploitasi habis-habisan sumber daya alam untuk hal-hal yang tidak perlu.Minimalis menghilangkan kejenuhan terhadap pemakaian banyak ornamen dekoratif, pernak-pernik aksesori. Karakter dan kualitas ruang-ruang yang tercipta ditentukan oleh perabot dan pernak-pernik aksesori di dalamnya. Minimalis adalah pola berpikir, bekerja, dan pandang baru dalam melihat desain sebagai refleksi cara hidup masyarakat urban yang serba praktis, ringan, efisien, dan penuh kesederhanaan.

Bangunan rumah dengan gaya ini memiliki ciri-ciri fasad antara lain menggunakan garis-garis vertikal sederhana, variasi kotak, permainan bidang, serta penataan 
ruang yang praktis dan lapang, menggunakan warna yang tidak terlalu mencolok, misalnya silver, abu-abu hitam, putih, dan pastel, adanya permainan pada permukaan dinding, misalnya gubahan, geometri dan penggunaan material, mengu-rangi hal-hal yang sifatnya ornamental dengan tujuan menyederhanakan karakter bangunan, pintu dan jendela rata, lurus dan tanpa ornamen sehingga matahari leluasa masuk ke dalam rumah.

\section{METODE PENELITIAN Metode Pencarian Data}

Pengumpulan data pada penelitian ini dilakukan dengan cara pengamatan terhadap kondisi seting objek amatan serta berbagai dokumentasi pribadi objek amatan.

\section{Observasi}

Yaitu teknik pengumpulan data yang bersifat non verbal. Sekalipun dasar utama daripada metode observasi adalah penggunaan indera visual, tetapi kita dapat juga melibatkan indera-indera lain seperti pendengaran, rabaan dan penciuman. Observasi umum dilakukan bagi awal dari kegiatan survei yang dapat dijalankan bersama dengan studi dokumentasi atau eksperimen.

\section{Metode Interview (wawancara)}

Metode wawancara adalah cara yang dipakai untuk memperoleh informasi melalui kegiatan interaksi sosial antara peneliti dengan yang diteliti. Di dalam interaksi itu peneliti berusaha mengungkapkan gejala yang sedang diteliti melalui kegiatan tanya jawab. Metode pengumpulan data kualitatif yang tidak dirancang secara khusus, sehingga pada saat dilakukan pengumpulan data, pertanyaan dapat berkembang sesuai dengan kebutuhan data yang akan dikumpulkan. Wawancara ini akan dilakukan kepada informan yang dipilih secara purposive di wilayah penelitian.

\section{Metode Analisis}

Metode analisis yaitu dengan cara menganalisa permasalahan apa saja yang ada pada proses penelitian, kemudian mencari solusi pemecahan masalah tersebut (sintesa).

\section{Langkah Penelitian \\ Cara Pengumpulan Data}

Pengumpulan data pada penelitian ini dilakukan dengan cara pengamatan terhadap kondisi seting objek amatan serta berbagai dokumentasi pribadi objek amatan.

\section{Jenis Data}

Data yang diperoleh dan digunakan dalam penelitian ini berupa studi kasus yang disajikan dalam bentuk pemetaan, dokumentasi studi kasus serta deskripsi sebagai penjelasan data yang ada.

\section{Deskripsi Lokasi Penelitian Deskripsi Umum}

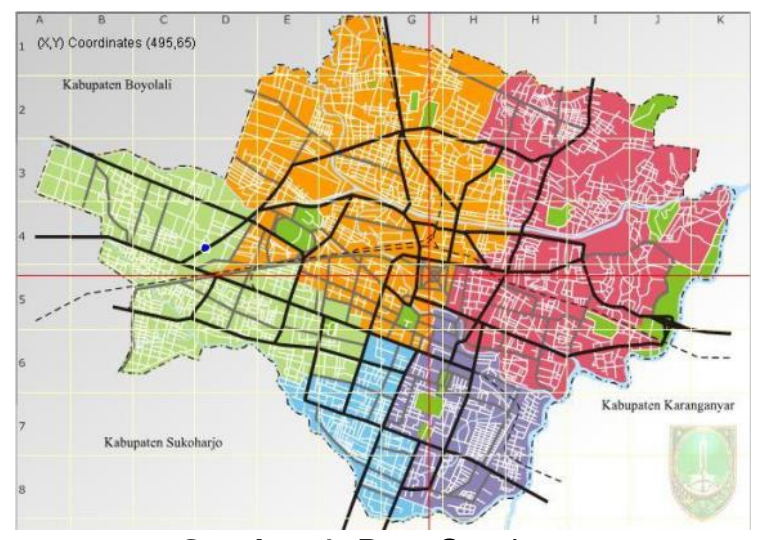

Gambar 1. Peta Surakarta

Sumber : www.google.com

Surakarta merupakan salah satu kota yang pada jaman dahulu termasuk kedalam karesidenan Surakarta, dimana kota-kota yang lainnya adalah Sukoharjo, Klaten, Boyolali, Sragen, Karanganyar, dan Wonogiri. Luas kota Surakarta adalah 44,06 km².

Kota Surakarta terletak di dataran rendah dengan ketinggian kurang lebih 92 meter diatas permukaan air laut, yang berarti lebih rendah atau hampir sama tingginya dengan permukaan sungai Bengawan Solo. Selain Bengawan Solo dilalui juga beberapa sungai, yaitu Kali Pepe, Kali Anyar dan Kali Jenes yang semuanya bermuara di Bengawan Solo. Kota Surakarta terletak diantara: 110 45' 15"- 110 45'35" Bujur Timur, 70 36' - 70 56' Lintang Selatan.Suhu udara maksimum 32,4 C dan suhu udara minimum $21,6^{\circ} \mathrm{C}$.

Sedangkan tekanan udara rata-rata adalah 1008,74 mbs dengan kelembaban udara $79 \%$. Kecepatan angin berkisar 4 knot dengan arah angin 188 serta beriklim panas. Lokasi penelitian berada di 5 kecamatan yaitu kecamatan Banjarsari, kecamatan Jebres, kecamatan Pasar Kliwon, kecamatan Serengan dan kecamatan Laweyan. 


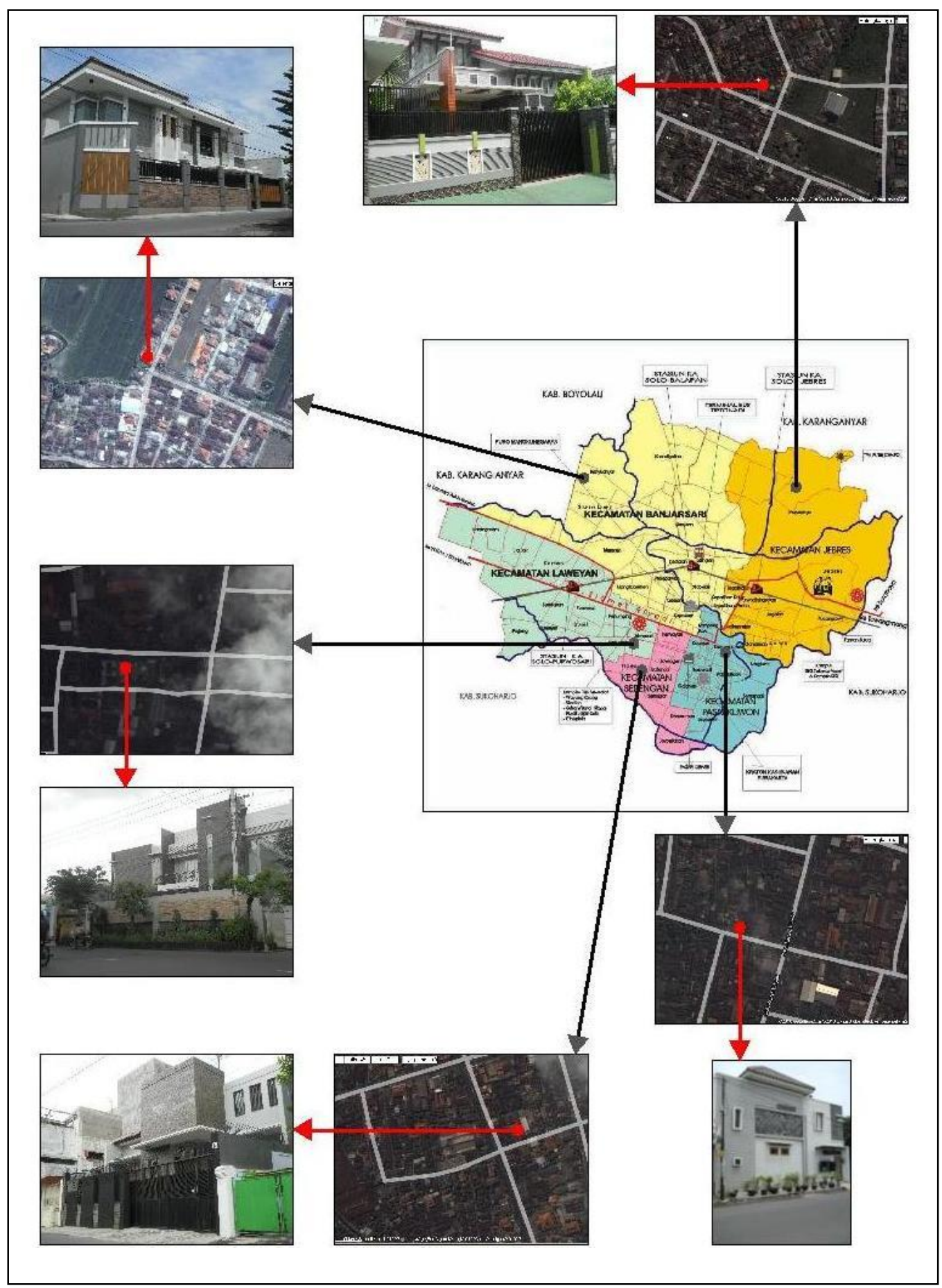

Gambar 2. Lokasi obyek penelitian 


\section{DISKRIPSI OBYEK PENELITIAN}

\section{Kasus 1:}

Rumah Minimalis 1 di Kecamatan Banjarsari (Jl. Pakel No 10, Sumber, Banjarsari)

Rumah Minimalis dikecamatan Bajarsari ini merupakan rumah pribadi yang mempunyai gaya arsitektur yang bercorak minimalis. Dengan menggunakan material alam seperti batu candi dan warna-warna natural, fasad rumah ini terkesan lebih alami dan tidak terlalu monoton. Selain itu, penggunaan jendela kaca yang besar ditunjukkan sebagai sumber cahaya serta mengurangi kesan massif pada fasad.

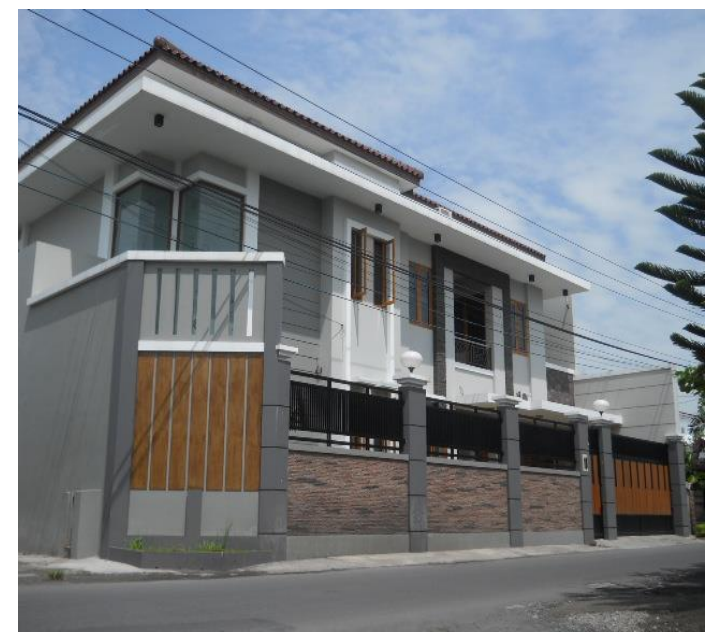

Gambar 3. Rumah minimalis kasus 1 Sumber : Dokumen pribadi, 2010

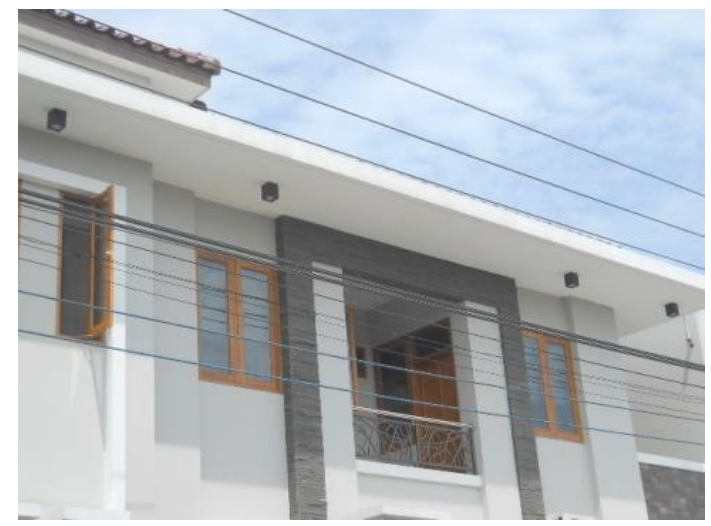

Gambar 4. Rumah minimalis kasus 1 Sumber : Dokumen pribadi, 2010

Pemilihan warna pada dinding dan garis-garis pada dinding memberikan nuansa elegan pada desain rumah.
Kasus 2:

Rumah Minimalis 2 di Kecamatan Jebres (Jl. Tamburadalam No. 1, Mojosongo, Jebres)

Rumah Minimalis dikecamatan Jebres ini merupakan rumah pribadi yang mempunyai gaya bercorak minimalis. Walaupun terdapat banyak ornamen pada rumah ini, bentuk fasad rumah tetap dikatagorikan fasad minimalis.

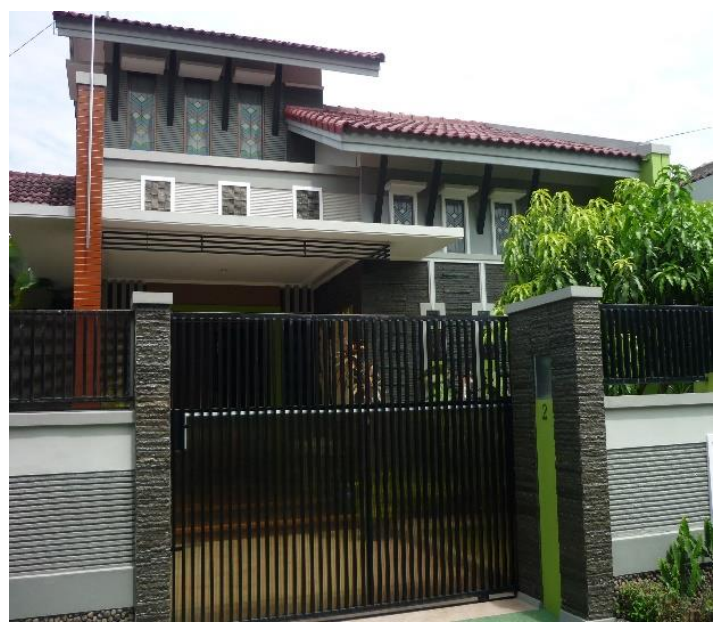

Gambar 5. Rumah minimalis kasus 2 Sumber : Dokumen pribadi, 2010

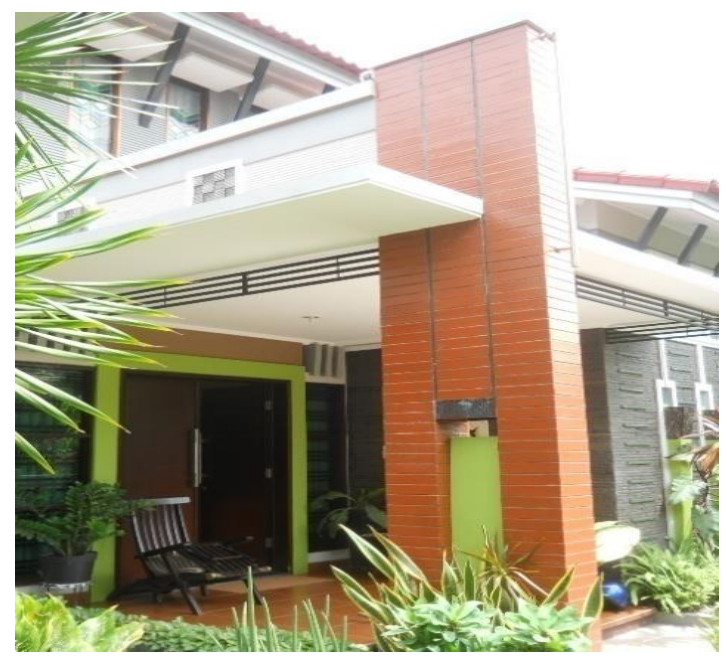

Gambar 6. Rumah minimalis kasus 2 Sumber : Dokumen pribadi, 2010

Ornamen lebih banyak terdapat pada dinding atau kolom. Ornamen pun bukanlah ornament yang sebenarnya, melainkan hanya sebagai salah satu variasi dari motif dinding. Penggunaan warna merah pada kolom penyangga teras ini menambah fariasi warna pada fasad ini. Penggunaan material batu alam pada dinding yang menghadap taman menambah kesan alami. 
Kasus 3 :

Rumah Minimalis 3 di Kecamatan Pasar Kliwon (Kedung Lumbu, Pasar Kliwon)

Rumah minimalis dikecamatan Pasar Kliwon merupakan rumah pribadi yang mempunyai gaya arsitektur yang bercorak minimalis.

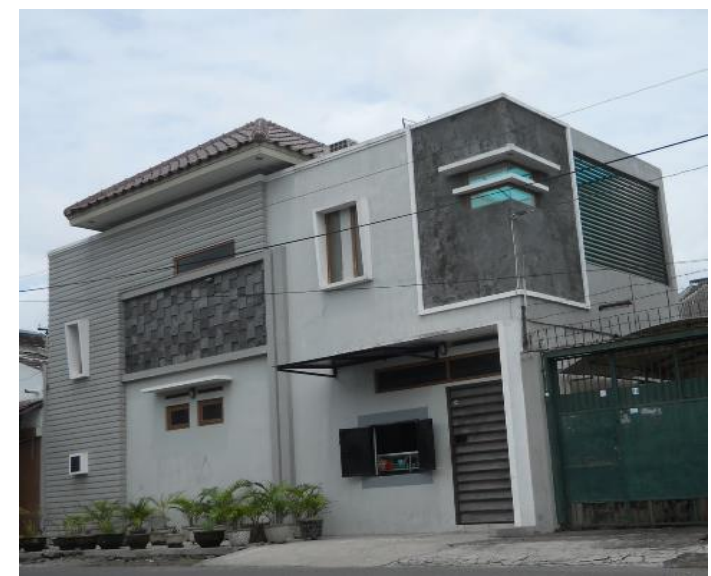

Gambar 7. Rumah minimalis kasus 3 Sumber : Dokumen pribadi, 2010

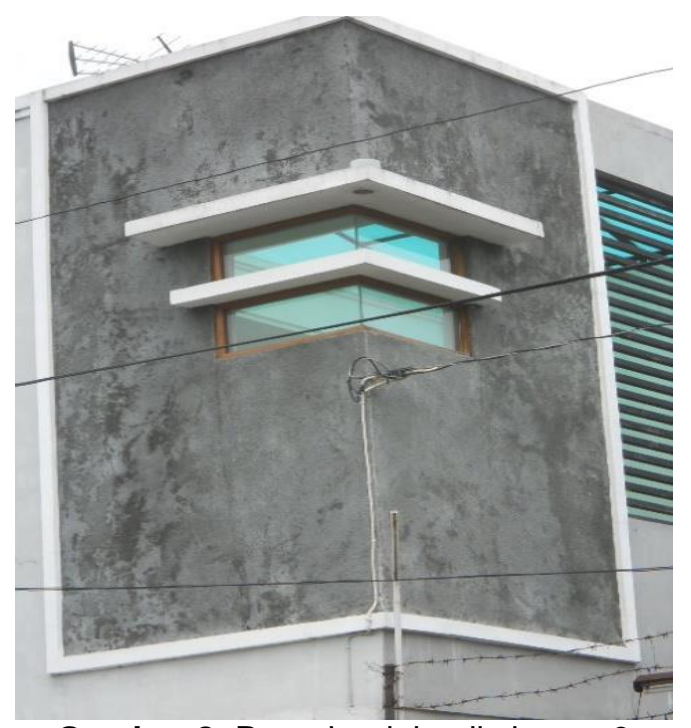

Gambar 8. Rumah minimalis kasus 3

Sumber : Dokumen pribadi, 2010

Walau fasad ini hanya terdiri dari dinding bangunan yang berbentuk sebuah boks besar, namun tidak terkesan monoton dikarenakan ornamen yang ada pada dinding tersebut. Penggunaan batu alam dan permainan garis vertikal dan horizontal membuat fasad ini terlihat menarik.
Kasus 4 :

\section{Rumah Minimalis 4 di Kecamatan Serengan (Jl. Brotojoyo No 4, Tipes, Sere-ngan)}

Rumah minimalis dikecamatan Serengan ini merupakan rumah pribadi yang mempunyai gaya arsitektur yang mempunyai corak minimalis. Tidak banyak modifikasi yang dilakukan pada desain fasad di rumah ini. Penggunaan jendela-jendela kaca yang besar ditunjukkan sebagai sumber cahaya serta mengurangi kesan masif pada fasad. Pemilihan warna pada dinding yang manis memberikan nuansa elegan pada desain rumah, serta penggunaan material batu alam pada dinding teras juga mendukung kedinamisan fasad.

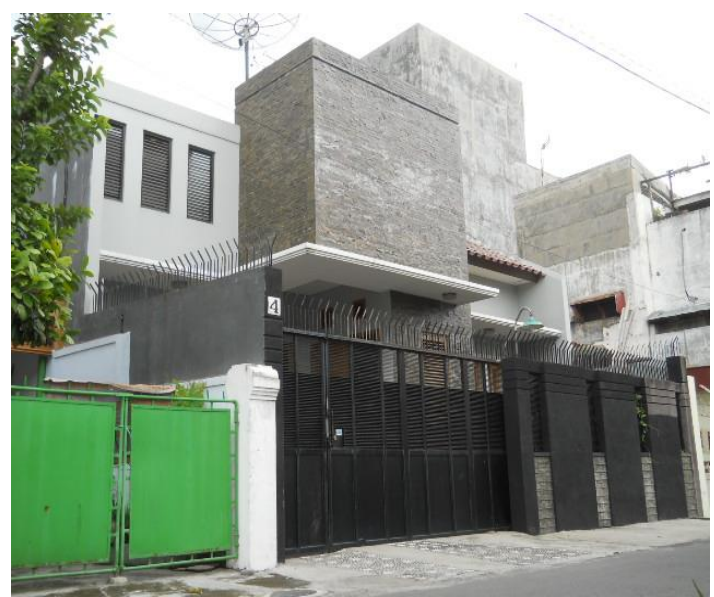

Gambar 9. Rumah minimalis kasus 4 Sumber : Dokumen pribadi, 2010

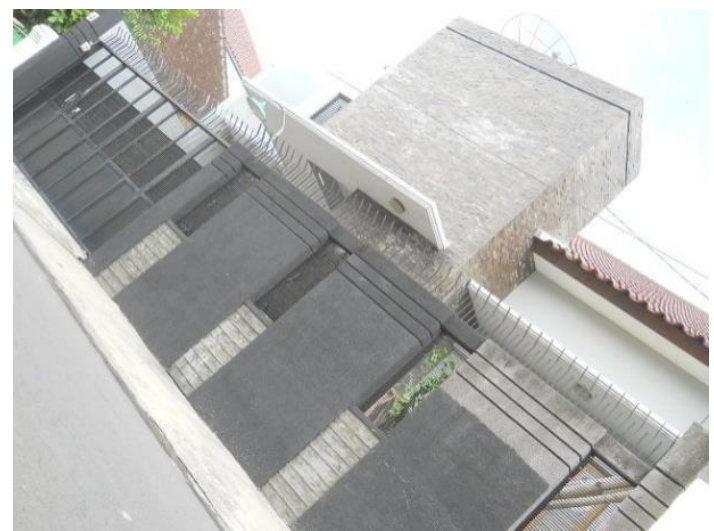

Gambar 10. Rumah minimalis kasus 4 Sumber : Dokumen pribadi, 2010 
Kasus 5 :

Rumah Minimalis 5 di Kecamatan Laweyan (JI. Dr Rajiman No 351, laweyan)

Rumah Minimalis dikecamatan Laweyan merupakan rumah pribadi yang mempunyai gaya arsitektur yang bercorak minimalis. Adanya unsur batu alam dan material kaca yang besar dapat melunakkan kesan monoton yang terdapat pada fasad ini.
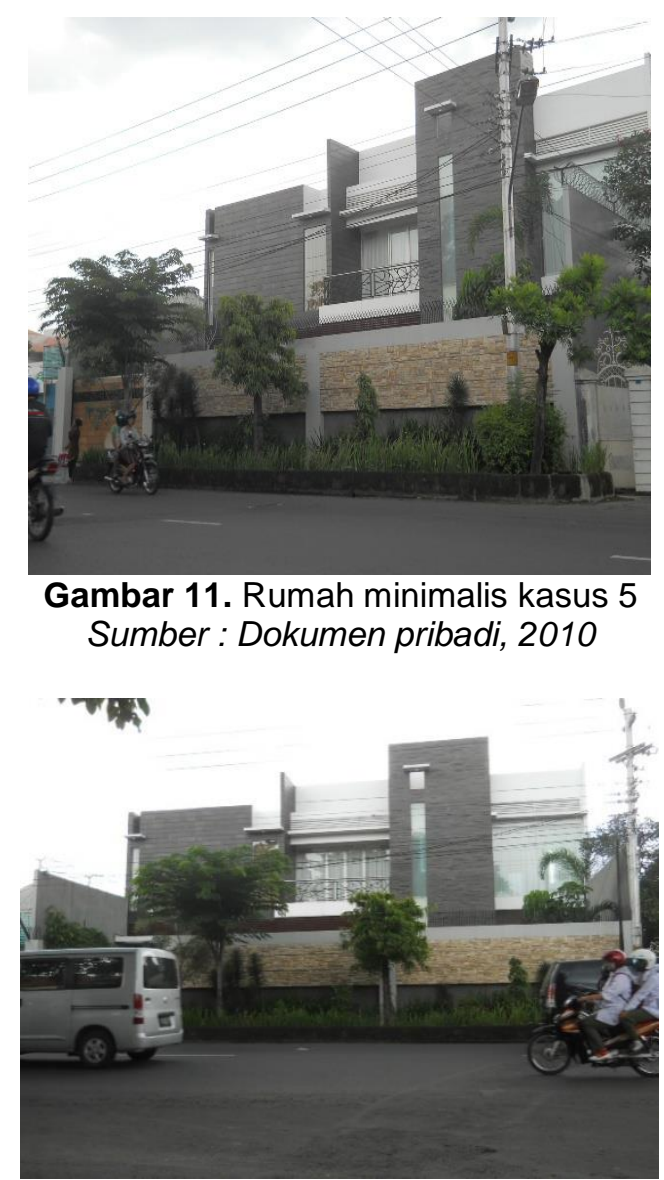

Gambar 12. Rumah minimalis kasus 5 Sumber : Dokumen pribadi, 2010

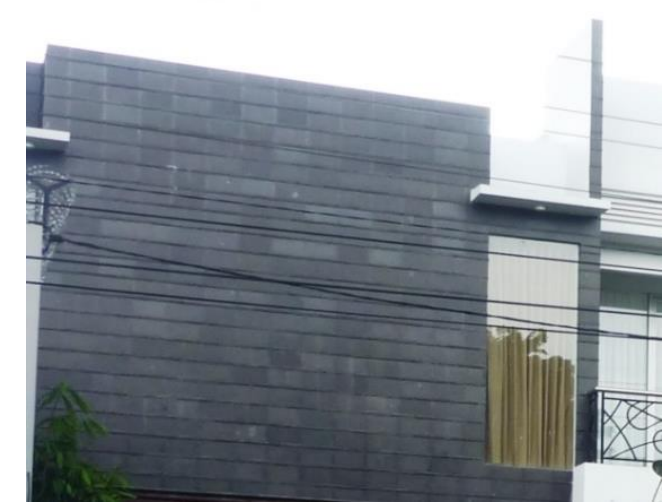

Gambar 13. Rumah minimalis kasus 5 Sumber : Dokumen pribadi, 2010

\section{HASIL DAN PEMBAHASAN}

Data hasil pengamatan lapangan selanjutnya dianalisis secara diskriptif.

\section{Analisa kasus 1}

. Tabel 1. Analisa Unsur-unsur Bentuk Bangunan Rumah Minimalis 1 (Kecamatan Banjarsari)

\begin{tabular}{|c|c|c|}
\hline $\begin{array}{l}\text { Para } \\
\text { meter }\end{array}$ & $\begin{array}{c}\text { Obyek } \\
\text { Penelitian }\end{array}$ & Analisis \\
\hline $\begin{array}{l}\text { Wujud } \\
\text { /Bentuk }\end{array}$ & & $\begin{array}{l}\text { Bentuk Bangu- } \\
\text { nan sederhana } \\
\text { dan mudah } \\
\text { dipahami de- } \\
\text { ngan tamba- } \\
\text { han ornament- } \\
\text { ornamen }\end{array}$ \\
\hline $\begin{array}{c}\text { Posisi/ } \\
\text { Orientasi }\end{array}$ & & $\begin{array}{l}\text { Bangunan } \\
\text { menghadap ke } \\
\text { Timur dan } \\
\text { berada } \\
\text { disebelah jalan. }\end{array}$ \\
\hline $\begin{array}{c}\text { Warna/ } \\
\text { Teksture }\end{array}$ & & $\begin{array}{l}\text { Warna dinding } \\
\text { putih dan } \\
\text { tekstur halus, } \\
\text { tekstur kasar } \\
\text { tercipta dari } \\
\text { ornament batu } \\
\text { alam. }\end{array}$ \\
\hline $\begin{array}{l}\text { Dimensi/ } \\
\text { Proporsi }\end{array}$ & & $\begin{array}{l}\text { Bangunan } \\
\text { terlihat lebih } \\
\text { besar daripada } \\
\text { bangunan } \\
\text { disekitarnya. }\end{array}$ \\
\hline Irama & & $\begin{array}{l}\text { Irama terlihat } \\
\text { dari penggu- } \\
\text { naan jenis } \\
\text { material yaitu } \\
\text { menggunakan } \\
\text { material kaca, } \\
\text { batu alam, } \\
\text { kayu, dan garis } \\
\text { lurus pada } \\
\text { dinding. }\end{array}$ \\
\hline Skala & & $\begin{array}{l}\text { Bangunan } \\
\text { terlalu kede- } \\
\text { pan, sehingga } \\
\text { dapat dilihat } \\
\text { dari arah } \\
\text { selatan dan } \\
\text { timur. }\end{array}$ \\
\hline
\end{tabular}


Analisa Kasus 2 :

Tabel 2. Analisa Unsur-unsur Bentuk Bangunan Rumah Minimalis 2 (Kecamatan Jebres)

\begin{tabular}{|c|c|c|}
\hline $\begin{array}{l}\text { Para } \\
\text { meter }\end{array}$ & $\begin{array}{c}\text { Obyek } \\
\text { Penelitian }\end{array}$ & Analisis \\
\hline $\begin{array}{l}\text { Wujud } \\
\text { /Bentuk }\end{array}$ & & $\begin{array}{l}\text { Bentuk } \\
\text { Bangunan } \\
\text { yang simple } \\
\text { dan mudah } \\
\text { dipahami. }\end{array}$ \\
\hline $\begin{array}{c}\text { Posisi// } \\
\text { Orientasi }\end{array}$ & & $\begin{array}{l}\text { Bangunan } \\
\text { menghadap ke } \\
\text { Timur dan } \\
\text { berada } \\
\text { disebelah } \\
\text { jalan. }\end{array}$ \\
\hline $\begin{array}{l}\text { Warna/ } \\
\text { Teksture }\end{array}$ & & $\begin{array}{l}\text { Warna dasar } \\
\text { putih dan abu- } \\
\text { abu, tekstur } \\
\text { kasar tercipta } \\
\text { dari ornamen } \\
\text { yang ada. }\end{array}$ \\
\hline $\begin{array}{l}\text { Dimensi/ } \\
\text { Proporsi }\end{array}$ & & $\begin{array}{l}\text { Bangunan } \\
\text { dengan } \\
\text { dimensi yang } \\
\text { cukup kecil } \\
\text { dan sederhana }\end{array}$ \\
\hline Irama & $M$ & $\begin{array}{l}\text { Irama terlihat } \\
\text { dari penguna- } \\
\text { an jenis mate- } \\
\text { rial yaitu } \\
\text { menggunakan } \\
\text { material kaca, } \\
\text { batu alam, ka- } \\
\text { yu, dan garis } \\
\text { lurus pada } \\
\text { dinding. }\end{array}$ \\
\hline Skala & and & $\begin{array}{l}\text { Skala } \\
\text { bangunan } \\
\text { didukung dari } \\
\text { penataan } \\
\text { tapak didepan } \\
\text { garis } \\
\text { bangunan. }\end{array}$ \\
\hline
\end{tabular}

Sumber : Analisis 2010
Analisa Kasus3

(Kecamatan Pasar Kliwon)

Tabel 3. Analisa Unsur-Unsur Bentuk Bangunan Rumah Minimalis 3 (Kecamatan Pasar Kliwon)

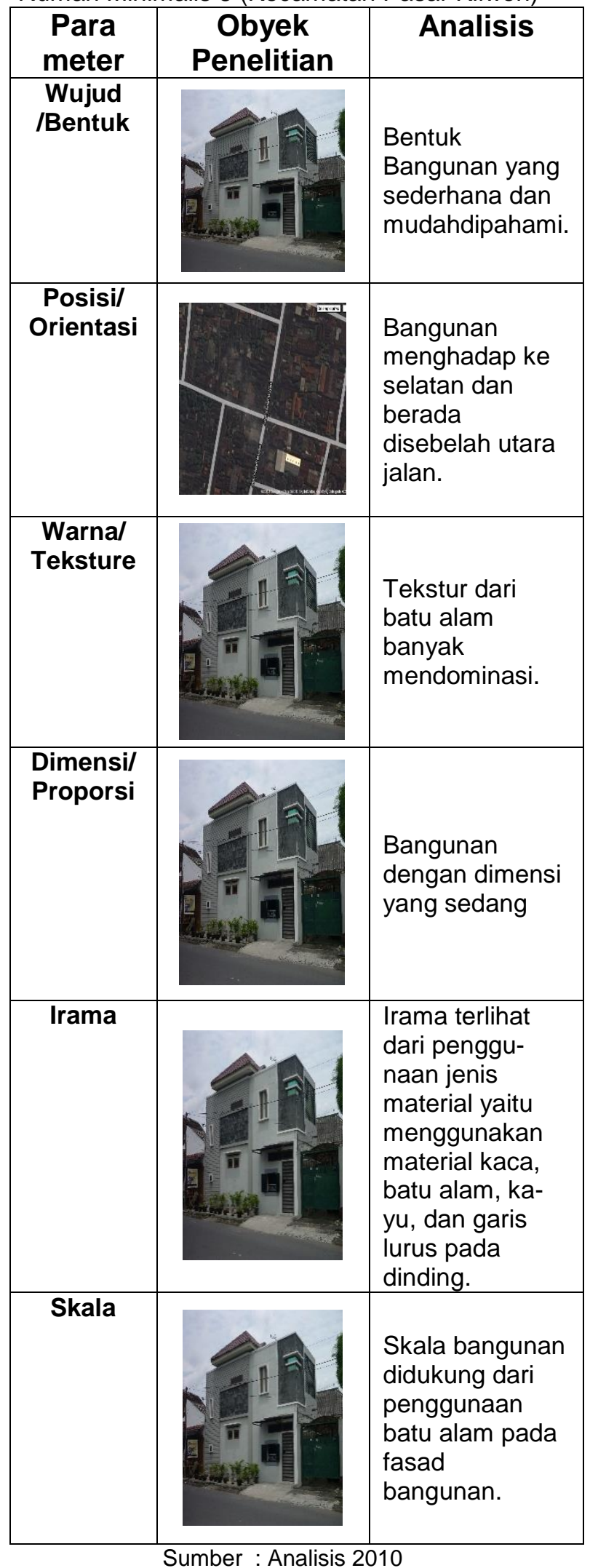


Analisa Kasus 4 (Kecamatan Serengan)

Tabel 4. Analisa Unsur-unsur Bentuk Bangunan

Rumah Minimalis 4 (Kecamatan Serengan)

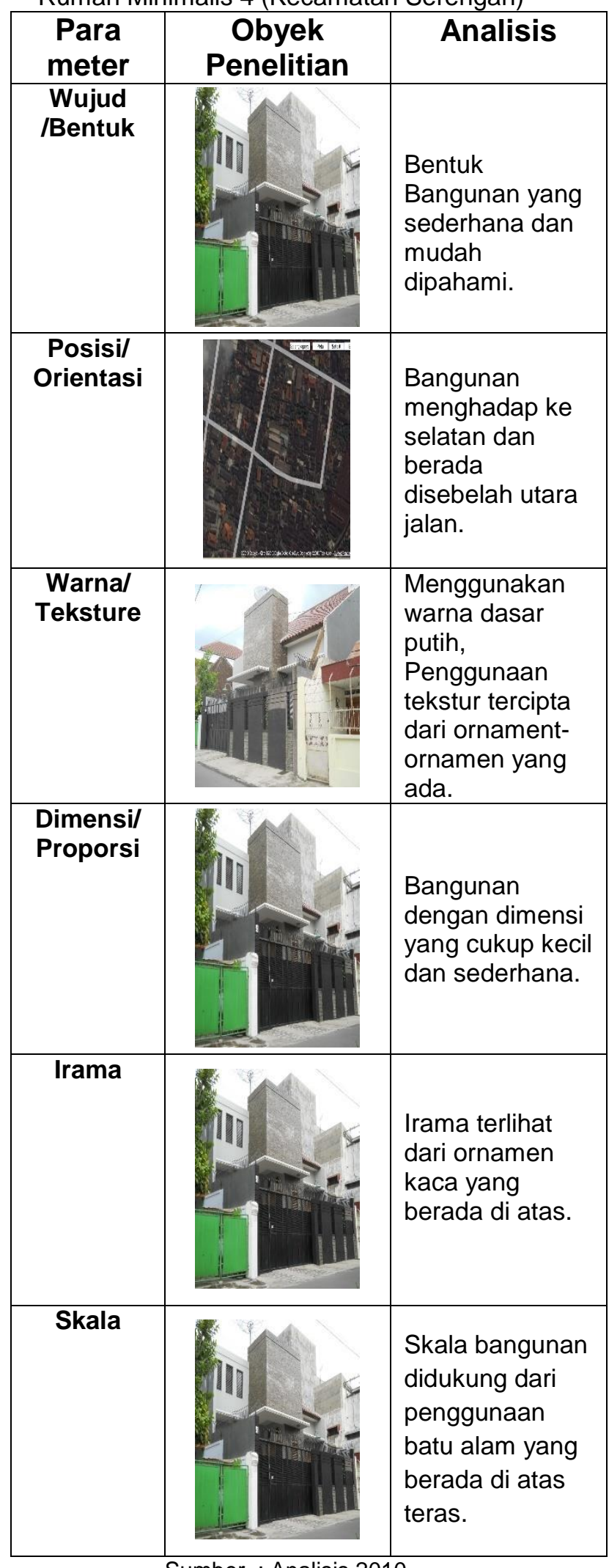

Analisa Kasus 5 (Kecamatan Pasar Kliwon)

Tabel 5. Analisa Unsur-unsur Bentuk Bangunan

Rumah Minimalis 5 (Kecamatan Pasar Kliwon)

\begin{tabular}{|c|c|c|}
\hline $\begin{array}{l}\text { Para } \\
\text { meter }\end{array}$ & $\begin{array}{c}\text { Obyek } \\
\text { Penelitian }\end{array}$ & Analisis \\
\hline $\begin{array}{l}\text { Wujud } \\
\text { /Bentuk }\end{array}$ & & $\begin{array}{l}\text { Bentuk } \\
\text { Bangunan yang } \\
\text { sederhana dan } \\
\text { mudah } \\
\text { dipahami. }\end{array}$ \\
\hline $\begin{array}{l}\text { Posisi/ } \\
\text { Orientasi }\end{array}$ & & $\begin{array}{l}\text { Bangunan } \\
\text { menghadap ke } \\
\text { utara dan } \\
\text { berada } \\
\text { disebelah } \\
\text { selatan jalan. }\end{array}$ \\
\hline $\begin{array}{l}\text { Warna/ } \\
\text { Teksture }\end{array}$ & & $\begin{array}{l}\text { Menggunakan } \\
\text { warna dasar } \\
\text { putih, tekstur } \\
\text { kasar tercipta } \\
\text { dari adanya } \\
\text { ornament batu } \\
\text { alam. }\end{array}$ \\
\hline $\begin{array}{l}\text { Dimensi/ } \\
\text { Proporsi }\end{array}$ & & $\begin{array}{l}\text { Bangunan } \\
\text { terlihat besar }\end{array}$ \\
\hline Irama & & $\begin{array}{l}\text { Irama terlihat } \\
\text { dari pengunaan } \\
\text { jenis material } \\
\text { yaitu } \\
\text { menggunakan } \\
\text { material kaca } \\
\text { dan batu alam. }\end{array}$ \\
\hline Skala & & $\begin{array}{l}\text { Skala bangunan } \\
\text { didukung dari } \\
\text { penggunaan } \\
\text { ornamen batu } \\
\text { alam. }\end{array}$ \\
\hline
\end{tabular}

Sumber : Analisis 2010 


\section{KESIMPULAN}

Karakteristik fasad rumah minimalis ditinjau dari unsur - unsur bentuk :

\section{Dari segi wujud}

Berdasarkan hasil survei dari semua bangunan wujud bangunanya merupakan bangunan yang sedarhana, geometris dan simple, karena bangunan tersebut terlihat sangat jelas dari bentuk bangunanya.

\section{Dari segi posisi}

Posisi bangunan kebanyakan berada tepat pada pinggir jalan, dan merupakan posisi yang sangat strategis yang dapat dilihat dari barbagai arah.

\section{Dari segi Warna}

Warna dari keseluruhan bangunan dominan berwarna putih abu-abu, yang banyak menggunakan ornamen-ornamen yang berwarna hitam.

\section{Dari segi Dimensi}

Dimensi pada keseluruhan bangunan kebanyakan berdimensi sebagai bangunan yang cukup kecil dari bangunan sekitarnya.

\section{Dari segi Irama}

Irama kebanyakan diperlihatkan pada ventilasi dan jendela yang terdapat pada sisisisi bangunan serta penggunaan material batu alam.

\section{Dari segi Skala}

Skala keseluruhan bangunan relatif besar dan didukung dari kondisi bangunan yang masih terlihat bagus.

Berdasarkan dari hasil penelitian tentang karakteristik fasad rumah minimalis di Surakarta, maka dapat disimpulkan bahwa ciriciri fasad rumah minimalis di Surakarta adalah:

1. Bentuk bangunan sederhana

2. Warna dasar putih dan abu-abu

3. Adanya garis vertikal sederhana

4. Adanya tempelan material batu alam yang dijadikan permainan pada permukaan dinding

5. Ornamen yang ada mempunyai bentuk yang sederhana

6. Pintu dan jendela rata

7. Pagar rumah dengan raling minimalis dan tempelan batu alam

8. Bentuk atap yang sederhana dan tidak adanya penggunaan talang

9. Kanopi dari cor beton dengan bentuk yang sederhana.

\section{DAFTAR PUSTAKA}

Arrasuli, Reyhan, 2009. Ragam Inspirasi Fasad Rumah Minimalis, Jakarta : GriyaKreasi .

Ching,Francisc D.K. 1996. Arsitektur Bentuk, Ruang dan Susunannya.Jakarta:Erlangga

Gantini, Christina,1996, Tipologi Bangunan, Buku Ajar Jurusan Teknik Arsitektur Winaya Mukti.

Krier, Rob. 2001. Komposisi Arsitektur. Jakarta:Erlangga.

Triyaningsih. 2007. Karakteristik Fasade Bangunan di Jalan Sudirman. Laporan Seminar Penelitian, UMS

http://repo.isi-dps.ac.id/143/1/Pengertian_Warna_dan_Tekstur.pdf

http://wapedia.mobi/id/Jebres,_Surakarta

http://satriowibisono.blogspot.com/2008/09/tekstur.html 